\title{
Numerical Simulations of the 1991 Limón Tsunami, Costa Rica Caribbean Coast
}

\author{
Silvia Chacón-Barrantes ${ }^{1}$ (D) and Natalia Zamora ${ }^{2,3}$
}

\begin{abstract}
The second largest recorded tsunami along the Caribbean margin of Central America occurred 25 years ago. On April 22nd, 1991, an earthquake with magnitude Mw 7.6 ruptured along the thrust faults that form the North Panamá Deformed Belt (NPDB). The earthquake triggered a tsunami that affected the Caribbean coast of Costa Rica and Panamá within few minutes, generating two casualties. These are the only deaths caused by a tsunami in Costa Rica. Coseismic uplift up to $1.6 \mathrm{~m}$ and runup values larger than $2 \mathrm{~m}$ were measured along some coastal sites. Here, we consider three solutions for the seismic source as initial conditions to model the tsunami, each considering a single rupture plane. We performed numerical modeling of the tsunami propagation and runup using NEOWAVE numerical model (Yamazaki et al. in Int J Numer Methods Fluids 67:2081-2107, 2010, doi: 10.1002/fld.2485 ) on a system of nested grids from the entire Caribbean Sea to Limón city. The modeled surface deformation and tsunami runup agreed with the measured data along most of the coastal sites with one preferred model that fits the field data. The model results are useful to determine how the 1991 tsunami could have affected regions where tsunami records were not preserved and to simulate the effects of the coastal surface deformations as buffer to tsunami. We also performed tsunami modeling to simulate the consequences if a similar event with larger magnitude Mw 7.9 occurs offshore the southern Costa Rican Caribbean coast. Such event would generate maximum wave heights of more than $5 \mathrm{~m}$ showing that Limón and northwestern Panamá coastal areas are exposed to moderate-to-large tsunamis. These simulations considering historical events and maximum credible scenarios can be useful for hazard assessment and also as part of studies leading to tsunami evacuation maps and mitigation plans, even when that is not the scope of this paper.
\end{abstract}

Key words: 1991 Limón earthquake, 1991 Limón tsunami, tsunami numerical modeling, Caribbean tsunamis, Costa Rica tsunamis.

1 Departamento de Fisica, National Tsunami Monitoring System (SINAMOT), Programa Red de Observación del Nivel del Mar e Investigación de Amenazas Costeras (RONMAC), Universidad Nacional de Costa Rica (UNA), Apdo. 86-3000, Heredia 40101, Costa Rica. E-mail: silviachaconb@gmail.com

2 Fundación Tropos, Apdo. 1309-2050, San José, Costa Rica.

3 National Research Center for Integrated Natural Disaster Management (CIGIDEN), Santiago, Chile.

\section{Introduction}

Tsunamis along the Caribbean basin have diverse tectonic sources, which are mainly related to convergence margins (López et al. 2015). Historical tsunamis have originated mostly along the Puerto Rico convergent margin, the Lesser Antilles subduction system, the South Caribbean Deformation Belt (SCDB), and the North Panamá Deformed Belt (NPDB). Strike-slip faults with normal component have triggered small tsunamis in the region (Fritz et al. 2013). Likewise, submarine landslides and volcanic eruptions have been an important source of tsunamis in the region (Harbitz et al. 2012; Lander et al. 2002).

About 105 tsunamis were triggered along the Caribbean basin in the last five centuries (NGDC/ WDS 2015). Historical records indicate that the tsunami hazard in the Caribbean Sea is mostly due to local sources. There are no records of basin-wide tsunamis generated in this region. Particularly, eight Caribbean tsunamis were generated along the North Panamá Deformed Belt (NPBD), the most important tectonic regime alongside the Caribbean margin of Central America, extending from central Costa Rica to Panamá. Therefore, local scenarios like the 1991 Limón tsunami are relevant on the assessment of tsunami hazard, as they could pose a high threat for Costa Rica and Panamá due to very short arrival times.

Several tsunami hazard studies have been conducted throughout the Caribbean Basin, mostly for the Lesser Antilles (Harbitz et al. 2012; Mercado and McCann 1998; Hayes et al. 2013; Roger et al. 2013; Zahibo et al. 2003). However, in the Central American region some regional studies have suggested low probability for tsunami generation at the Caribbean Coast (Løvholt et al. 2012; López et al. 2015; Parsons and Geist 2008; Harbitz et al. 2012), unlike the Pacific Coast where tsunamis are more frequent. For 
example, two tsunami-earthquakes have occurred in the last 25 years in the Pacific coast of Central America, Nicaragua 1992 and El Salvador 2012 causing local but rather large tsunamis (Borrero et al. 2014; Satake 1994). For the Caribbean coast of Central America Geist and Parsons (2006) published a 30-year tsunami probability map with 5-9\% probability of exceeding $0.5 \mathrm{~m}$ in Puerto Limón, Costa Rica. Despite the estimated low probability for Costa Rica, historical tsunami occurrence and runups at the Caribbean coast are comparable to the Pacific coast. While only moderate earthquakes appear to be common in both shores, these events represent a threat to coastal cities as seen with the $1991 \mathrm{Mw} 7.6$ Limón earthquake and tsunami.

After the 1991 Limón tsunami, Nishenko et al. (1995) recommended defining an evacuation area based on a fixed distance from the shoreline, but the same work recognizes significant differences on runup due to the presence of coral reefs and river mouths. Tsunami inundation depends on topographic and bathymetric features; therefore it is advisable to base the evacuation region on results of systematic tsunami modeling, accounting for those features. In the present work tsunami modeling is performed based on several source models for 1991 Limón earthquake, and a hypothetical worst credible scenario. The scope of this modeling is to contribute on the definition of inundation regions within the south Caribbean coast of Costa Rica, based on a possible recurrence of 1991 event and the assumption of a similar yet more severe scenario along the same source region.

\subsection{Tectonic Setting}

Costa Rica lies in the western part of the Caribbean plate. Complex tectonics prevails due to the interaction of several tectonic plates at the Central America convergent margin. Along the Pacific side, the Middle America Trench (MAT) is one of the most prominent tectonic features caused by the Cocos plate subduction beneath the Caribbean plate and the Panamá microplate (Fig. 1). This margin represents one of the most seismically active regions along Central America.
Towards the Caribbean side, the North Panamá Deformed Belt (NPDB) represents the convergence between the Caribbean plate and the Panamá block (Adamek et al. 1988; Camacho et al. 2010; Protti and Schwartz 1994) at a rate of $7 \mathrm{~mm} /$ year (Trenkamp et al. 2002). This deformation zone extends from Costa Rica to the Urabá Gulf in Colombia (Silver et al. 1990) where most seismicity occurs along the over-thrusting system. The Panamá block conforms an area of deformation whose boundaries remain unclear (Pennington 1981; Fernández 2013; Lundgren et al. 1999). The topographic features such as the Limón-Moín and Manzanillo promontories in Costa Rica are part of an accretionary complex, where these sedimentary formations have been progressively offscraped along a basal decollement and accreted to the region (Silver et al. 1995; Plafker and Ward 1992; Silver et al. 1990). While the limits of the over-thrusting system of the Panamá block towards the Caribbean plate are a scientific debate (e.g., Adamek et al. 1988; Camacho et al. 2010; Wolters 1986), it has been recognized that, at least along the central Panamá, there is clear evidence of a Wadatti-Benioff zone (WB) demonstrating an active subduction beneath the Panamá block. The WB extends from central Panama to the Gulf of Urabá, Colombia (Camacho et al. 2010).

Due to the distinct seismicity patterns, the NPDB has been separated in three seismo-tectonic areas: western, central, and eastern segments by Camacho and Víquez (1993). They suggest the western segment can be divided in two subregions following approximately the Costa Rica-Panamá border. Along the Costa Rican margin most earthquake epicenters have been registered inland, opposite to the Panamá segment where earthquakes occur commonly offshore (Fig. 1, inset). It is important to note that most of the tsunamigenic earthquakes have originated along the Costa Rican segment. According with Benito et al. (2012) this region presents the highest seismic hazard of Central America Caribbean coast, together with the eastern segment of the NPDB along Panamá.

\subsection{Historical Events at the NPDB Western Segment Prior to 1991 Limón Earthquake and Tsunami}

There are records of several earthquakes in the Caribbean coast of Costa Rica, some of which 


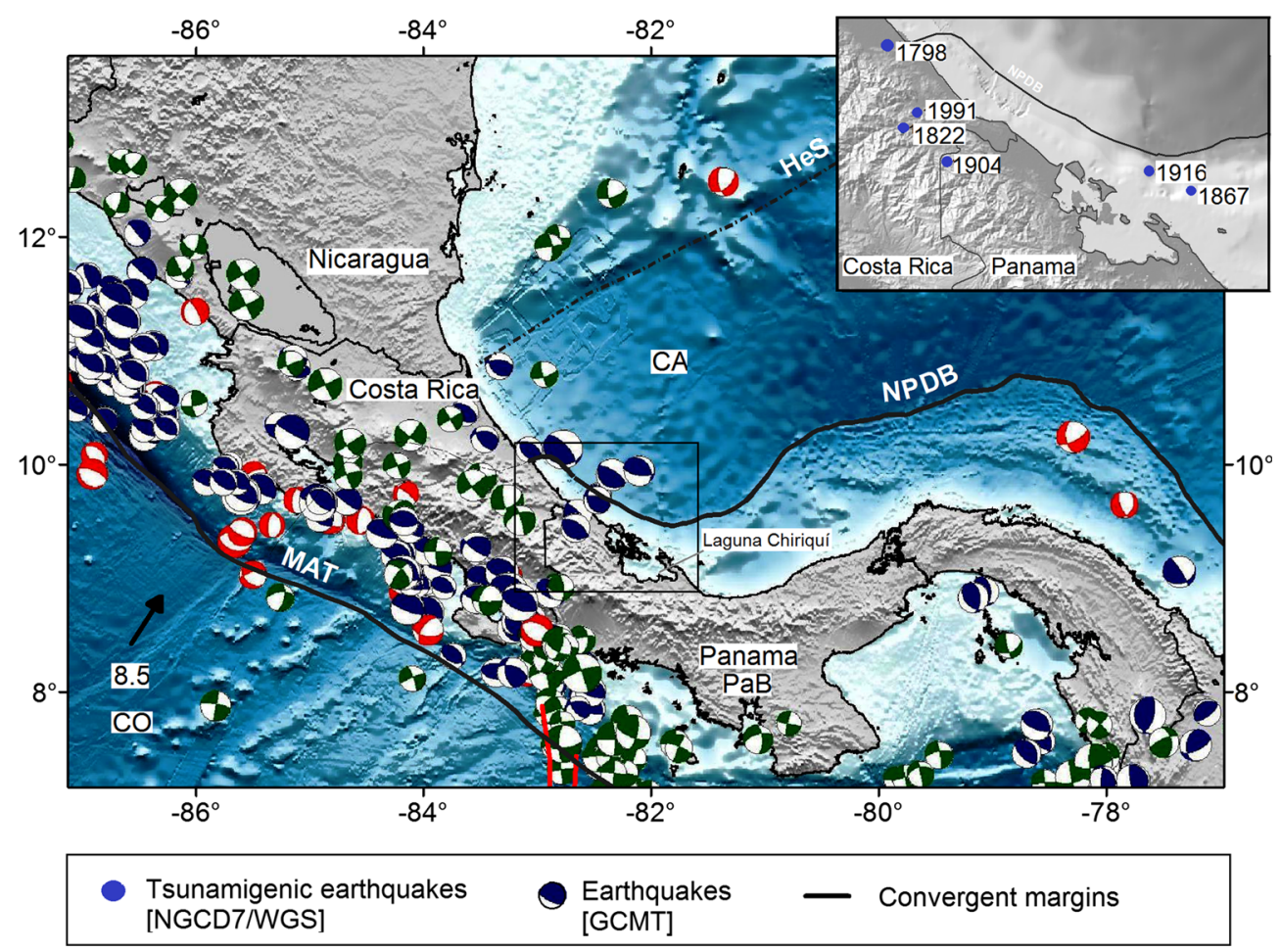

Figure 1

Tectonic setting and seismicity $(\mathrm{Mw}>6)$ along Central America. Black lines show the convergent margins. Arrows show the convergence rate in cm/year. HeS hess scarpment, $M A T$ middle America trench, NPBD Northern Panamá deformation belt, $C A$ Caribbean plate, $C O$ Cocos plate, NAZ Nazca plate, PaB Panamá Block. The inset shows tsunamigenic earthquakes between 1750-2016 (NGDC)

triggered local tsunamis (Fernández-Arce et al. 2000). The first historical record available in this region dates to the year 1746 when the San Fernando fortress at Boca Matina was partially destroyed by an earthquake, although there is no clear evidence of its location (Boschini and Montero 1994). In February 21 st of 1798 , a strong sound was reported to come from the sea after a strong earthquake and there were reports of strange sea behavior, making the villagers fear an inundation (Boschini and Montero 1994; Camacho and Víquez 1993). Due to the date and the very scarce population at that time there are no reports of the earthquake from the rest of the country, which could confirm its origin at the Caribbean region of Costa Rica.

An event on May 7th, 1822 characterized by increasing water levels in bays was reported in Costa Rica (Camacho and Víquez 1993; Boschini and Montero 1994), and was very likely triggered by a Ms 7.9 earthquake (Camacho and Víquez 1993). This earthquake was originally located at the Pacific coast of Costa Rica, at the Osa region (Boschini and Montero 1994; Camacho and Víquez 1993) but was later relocated along the North Panamá Deformed Belt (NPDB) based on the coseismic coastal uplift reported at Mona Point and Grape Point (Boschini and Montero 1994; Camacho and Víquez 1993). Data from isoseismic map comparing MMI VI (Modified Mercalli Intensity) contours for the 1822 and 1991 earthquakes shows that the region affected with high ground motions covered a larger area in the 1822 event, which might be an indication of its larger magnitude compared to 1991 event (Boschini and Montero 1994). However, the same authors indicate that due to uncertainties on one intensity report at the northwest part of Costa Rica and a confusion between Monkey Point and Mona Point, the area covered by the MMI VI might be the same for both earthquakes suggesting similar magnitude and close epicenter (Boschini and Montero 1994). A recurrence time of 200 years for these events in this region has been suggested (Suárez et al. 1995). Other studies 
mentioned uplifted coastal terraces as indicators that events larger than the 1991 Limón earthquake could occur between 200 and 1100 years (Denyer et al. 1994; Plafker and Ward 1992).

Subsidence was registered at Zapodilla Island at Chiriquí Lagoon, Panamá (Fig. 1), after the 1867 earthquake whose magnitude is unknown. Similar subsidence was reported after the 1991 Limón earthquake at the same island suggesting similar sources (Camacho and Víquez 1993). However, there are no tsunami reports that could be related to the 1867 earthquake.

On December 20th, 1904 an earthquake with magnitude Ms 7.0 struck Costa Rica and Bocas del Toro, Panamá. In Costa Rica the earthquake was felt stronger at the Caribbean coast and there is a report of submerged reefs remaining visible after the earthquake (Camacho and Víquez 1993). There are no tsunami reports associated and other authors located the earthquake as part of the subduction of the Osa segment at the south Pacific coast of Costa Rica (Pacheco and Sykes 1992). There is not enough information to determine whether this earthquake was originated at the Pacific or Caribbean coast of Costa Rica.

On April 26th of 1916 an earthquake Ms 7.3 at Bocas del Toro, Panamá caused a local tsunami (Camacho and Víquez 1993). The source region was very close to the Costa Rican border. However, there are no tsunami reports at Costa Rica. All the earthquakes mentioned here except 1916 and very likely 1867 belong to the Costa Rican margin along the western segment of the NPDB (Camacho and Víquez 1993).

\subsection{The 1991 Limón Earthquake and Tsunami}

On April 22nd, 1991 an earthquake magnitude Mw 7.7 occurred along southeastern Costa Rica with epicenter at Sixaola. This event occurred along the back-arc thrusting system of the Caribbean plate beneath the Panamá block (Schwartz 1995). The earthquake triggered a tsunami that affected the southern Caribbean coast of Costa Rica and Bocas del Toro province in Panamá. This earthquake was the largest of the instrumental age in Costa Rica (Boschini and Montero 1994) and the only tsunami for which deaths have been reported there (Nishenko et al. 1995). However, the earthquake caused considerably more damage than the tsunami and consequently the tsunami effects have remained relatively unknown to the public.

The tsunami had maximum runup of more than $2 \mathrm{~m}$ at Punta Uva, Costa Rica and up to $3 \mathrm{~m}$ at Panamá. It was recorded in three tidal gauges at Coco Solo in Panamá, Magueyes Island in Puerto Rico and Limetree in St. Croix U.S. Virgin Islands. Coco Solo is located at the entrance of the Panamá Canal and the tsunami recorded there was only in the order of centimeters (Nishenko et al. 1995). Also, it is important to note that coseismic uplift of the reef caused by 1991 earthquake has been measured throughout the Limón coast similar to what was reported for the 1904 earthquake (Denyer et al. 1994; Suárez et al. 1995; Plafker and Ward 1992) and its sediment deposits along Costa Rican coast were very similar to those left by the 1822 tsunami (Nishenko et al. 1995). Both similarities might indicate that tsunamis have relatively high frequency in this region, yet it is still difficult to establish confident recurrence periods.

\section{Methods}

\subsection{Numerical Model}

Tsunami numerical simulations have been performed with NEOWAVE code (Yamazaki et al. 2010). NEOWAVE was employed using hydrostatic approach and the static vertical coseismic deformation calculated by Okada model (Okada 1985) as initial condition to estimate tsunami propagation and inundation. NEOWAVE updates for ground deformation, which is of particular importance for inundation modeling in cases like this, since part of the deformation occurs beneath land.

Four nested grids have been set up based on a 1 arcmin grid covering the Caribbean Sea named grid 1 (Fig. 2). This main grid was constructed as part of an international effort to create a tsunami-modeling platform for the region (López et al. 2016). Three smaller grids were nested to the main grid covering the Costa Rican Caribbean region from the south Caribbean coast to Limón city, with resolutions of 12, 3 , 


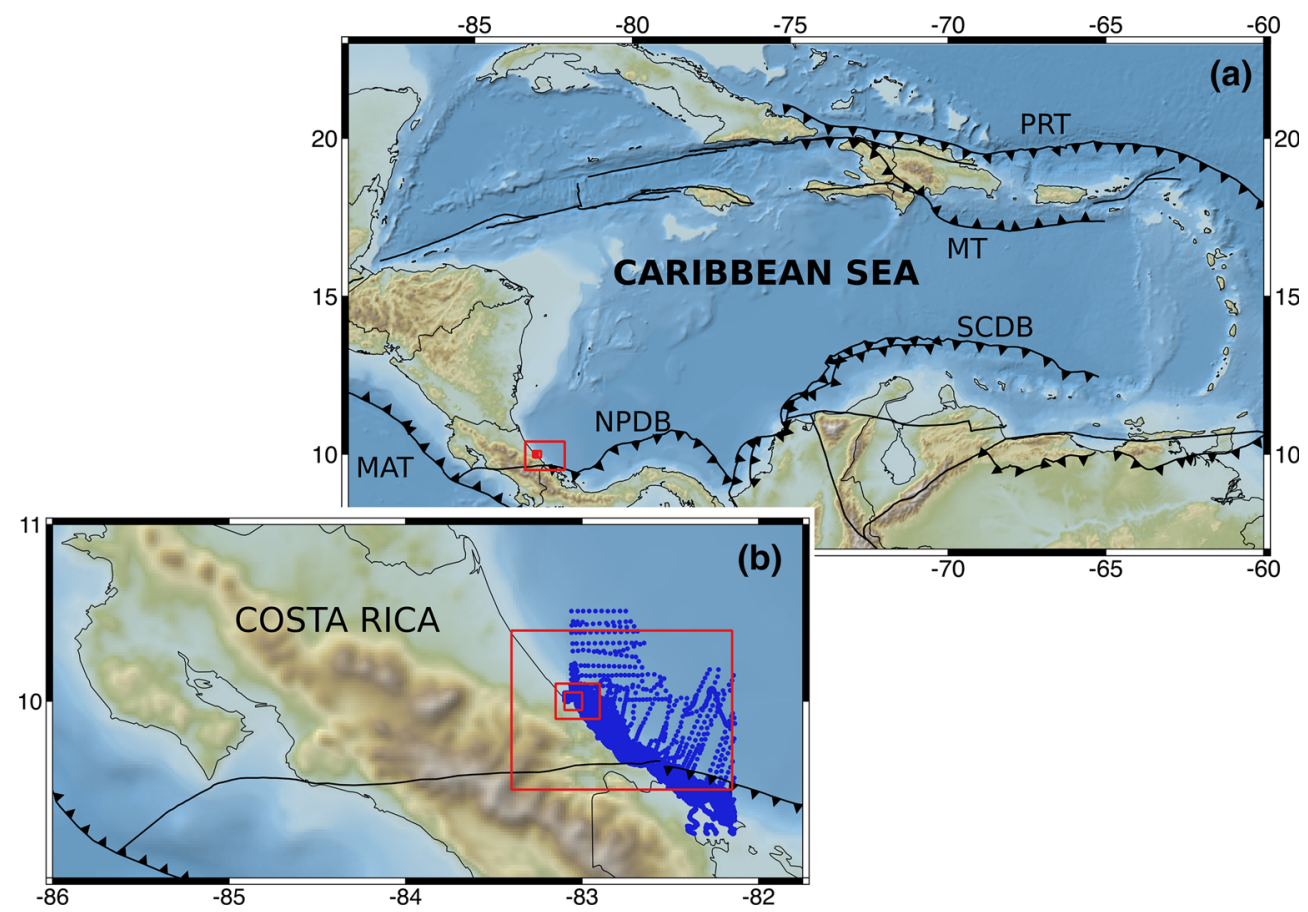

Figure 2

Nested grids setup. Grid 1 extent is depicted in (a) and grid 2, 3, and 4 are shown with red lines in (a) and (b). The depth points from nautical charts are plotted with blue dots in (b). MAT Middle America Trench, NPDB North Panamá Deformed Belt, SCDB South Caribbean Deformed Belt, MT Muertos Trough, PRT Puerto Rico Trench

and 1 arcsec, named grids 2, 3, and 4, respectively. The Courant-Friedrichs-Lewy stability number (CFL) for the grids was $0.47,0.59,0.50$, and 0.40 , for grids $1-4$, respectively. The bathymetry for those grids was built after merging SRTM90 topography, GEBCO bathymetry, and digitized nautical charts 28048 and 28051 from the Defense Mapping Agency Hydrographic/ Topographic Center of the United States of America. Those nautical charts are the only source of bathymetry data in that region with scales of 1:145,290 and 1:15,000; and their data was obtained from surveys performed in 1938 and 1987, respectively. The bathymetric datasets mentioned above were interpolated to the resolution of grids 2, 3 and 4 .

Due to low frequency of tsunamis at the Caribbean Sea, there are no tsunami records at Limón tidal gauge that could verify the model setup. However, results of the model setup in López et al. (2016) have been successfully compared with results of RIFT and SIFT numerical models (IOC/UNESCO 2014) for the CaribeWave15 exercise (IOC/UNESCO
2015), as part of the tsunami-modeling platform developed for the Caribbean.

\subsection{Field Data of the 1991 Limón Earthquake and Tsunami}

Plafker and Ward (1992), hereafter referred as PW92, measured the coseismic deformation caused by 1991 earthquake at 34 points along the Costa Rican shore and one point at Panamá shore (green dots, Fig. 3). They also performed a post tsunami survey in Costa Rica and measured tsunami runup at 10 points (green triangles in Fig. 3); giving estimated time arrivals (ETA) for 4 of these sites. Camacho (1994) also performed a post tsunami survey along 14 sites in Panamá and one in Costa Rica (blue triangles, Fig. 3). However, their only site in Costa Rica, Gandoca, is the same as in PW92, the former reported between 1 and $2 \mathrm{~m}$ of runup and the later $1.25 \mathrm{~m}$, consequently the data provided by Camacho (1994) will not be considered in this study. 

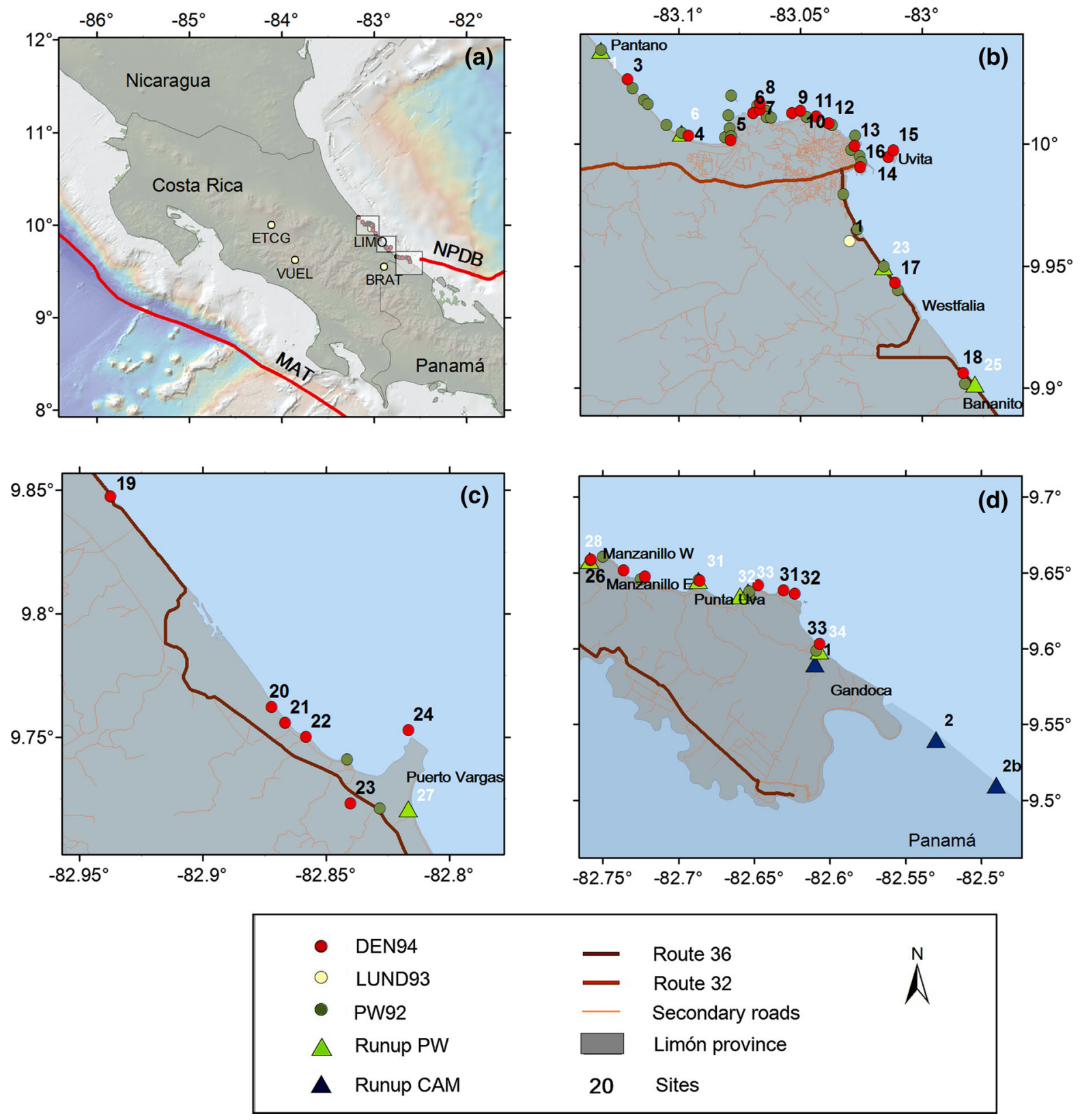

Figure 3

Location of points where runup (triangles), and coseismic deformation (dots) were measured by Camacho (1994) (dark blue triangles), PW92 (green dots, green triangles), DEN94 (red dots) and LUND93 (yellow dots). MAT Middle America Trench, NPDB Northern Panama Deformed Belt

Denyer et al. (1994), hereafter referred as DEN94, measured the coseismic deformation at 33 points (red dots, Fig. 3). Lundgren et al. (1993), hereafter LUND93, published data obtained during GPS campaigns carried between February and July 1991, along four sites, two of them within the rupture area: LIMO and BRAT (yellow dots, Fig. 3a).

Some of the sites reported by PW92 and DEN94 with coseismic deformation data were not considered here due to inconsistencies between the coordinates 
Table 1

Fault parameters of the modeled seismic solutions: $P W$ refers to Plafker and Ward (1992) and GOES to Goes et al. (1993)

\begin{tabular}{llll}
\hline Name & PW1 & PW2 & GOES \\
\hline Longitude epicenter & -83.103 & -83.111 & -83.073 \\
Latitude epicenter & 10.041 & 10.029 & 9.685 \\
Longitude shallow corner & -83.103 & -83.111 & -83.131 \\
Latitude shallow corner & 10.041 & 10.029 & 10.038 \\
Strike & 120 & 105 & 103 \\
Dip & 30 & 25 & 17 \\
Rake & 90 & 90 & 63 \\
Min. depth $(\mathrm{km})$ & 2 & 2 & 3 \\
Mean slip $(\mathrm{m})$ & 2.3 & 2.1 & 2.8 \\
$L(\mathrm{~km})$ & 71 & 96 & 58 \\
$W(\mathrm{~km})$ & 28 & 50 & 48 \\
Mo $\left(\mathrm{N}^{*} \mathrm{~m}\right)$ & $1.4 \times 10^{20}$ & $3.3 \times 10^{20}$ & $2.6 \times 10^{20}$ \\
Mw & 7.4 & 7.65 & 7.58 \\
\hline
\end{tabular}

provided in tables and in maps in their respective publications.

\subsection{Seismic Source of the 1991 Limón Tsunami}

There are three different seismic solutions published for the 1991 Limón earthquake. Plafker and Ward (1992) generated two solutions inverting coseismic uplift field data and tsunami arrival time. In their first solutions they fixed the strike and in the second they allowed the strike to vary. Goes et al. (1993) inverted both surface and body seismic waves. Lundgren et al. (1993) used the focal geometry of the Harvard CMT solution and adjusted the slip magnitude and fault dimensions to match horizontal and vertical deformation measured by non-continuous GPS data. So far, there has not been agreement on which solution correlates better with the earthquake and tsunami effects.

In this work we use the seismic parameters given by the three references above to model the tsunami using a single rupture plane with homogeneous slip. Although a rupture with those characteristics is very unlikely, there is not enough information to use a different approach. Subduction zone characterization, coupling and seismogenic zone heterogeneities are lacking for the western segment of the NPDB; also there are not enough tsunami data to perform a tsunami inversion to account for such features.

The parameters of the seismic solutions employed as tsunami sources are provided in Table 1: PW1 and PW2 from PW92 and GOES from Goes et al. (1993). The given scenarios range between magnitudes $\mathrm{Mw} 7.4$ and 7.65 , and fault average slip varies from 2.1 to $2.8 \mathrm{~m}$. Lundgren et al. (1993) provided a fourth seismic solution. However, this solution is substantially different from the other three, representing a much larger earthquake with an average slip of $5.8 \mathrm{~m}$ and $\mathrm{Mw} 7.79$ and therefore was not considered in this work.

\subsection{Seismic Source for a Hypothetical Worst Credible Seismic Source Offshore Limón (Mw 7.9)}

The NPDB could have the potential of rupturing earthquakes of magnitudes around $\mathrm{Mw} 8$ (Benito et al. 2012). Based on the extent of the western NPDB along the Costa Rican segment and considering similar characteristics of the 1991 event, a worst credible scenario is suggested here. We define a shallow seismic source with magnitude Mw 7.9 rupturing an area of $4940 \mathrm{~km}^{2}$ with an average slip of $5.5 \mathrm{~m}$, assuming scaling relations (Blaser et al. 2010). It has been assumed that such events could have a recurrence period of 500-1000 years based on the convergence rate and total release of accumulated slip in a strongly coupled seismogenic zone. This source was one of the scenarios for CaribeWave17 tsunami exercise in February 2017. The fault parameters are detailed in Table 2.

\section{Results}

\subsection{Limón Earthquake and Tsunami}

Figure 4 shows the coseismic deformation obtained with the source models considered for

Table 2

Fault parameters of the hypothetic worst credible scenario $M w 7.9$

\begin{tabular}{|c|c|c|c|c|c|c|c|c|c|}
\hline Name & Strike & Dip & Rake & Min. depth (km) & Mean slip (m) & $L(\mathrm{~km})$ & $W(\mathrm{~km})$ & Mo $\left(\mathrm{N}^{*} \mathrm{~m}\right)$ & $\mathrm{Mw}$ \\
\hline LIM & 122 & 25 & 90 & 2 & 5.5 & 130 & 38 & $5.5 \times 10^{20}$ & 7.90 \\
\hline
\end{tabular}


Figure 4

Coseismic deformation obtained from the seismic solutions of a PW1: Plafker and Ward (1992) solution 1, b PW2: Plafker and Ward (1992) solution 2, and c GOES: Goes et al. (1993). The thick dashed lines show the surface projection of the fault plane. The color scale is in meters and the contour lines correspond to coseismic deformation of $-0.1,0.4$, and $0.8 \mathrm{~m}$, respectively.

1991 Limón tsunami. Among all the solutions, GOES resulted in the smallest uplift of nearly $1.05 \mathrm{~m}$.

PW1 and PW2 seismic solutions were obtained fitting the maximum coseismic deformation at the Limón-Moín promontory, therefore their maximum coseismic uplift was located there (Fig. 4a, b). At the GOES solution, Limón-Moín promontory lies within the fault rupture area and the maximum deformation axis, but the maximum values were obtained at the sea, southeast of the promontory, mainly due to the $63^{\circ}$ rake (Fig. $4 \mathrm{c}$ ).

The maximum coseismic uplift measured by PW92 was $1.57 \mathrm{~m}$ at site 12 (Fig. 5a) and by DEN94 was $1.85 \mathrm{~m}$ at site 10 Piuta-Playa Bonita (Fig. 5b). In both sites all the modeled sources underestimated the runup by at least $50 \mathrm{~cm}$. PW1, PW2, and GOES underestimated the measurements at the central Caribbean coast as well but adjusted better to the rest of the points. In general, the PW92 (Fig. 5a) deformation data are much better resolved by the solutions modeled here than DEN94 deformation data (Fig. 5b). The normalized root-mean-square deviation (NRMSD) was smaller on locations of PW92 dataset than on locations of DEN94 dataset for the three solutions (Table 3). The best adjustment was obtained for PW92 data with PW1 solution and the worst for DEN94 data with GOES solution.

The comparison between the measured and the simulated runup for the surveyed sites on PW92 are plotted in Fig. 6. The results from both PW1 and PW2 fit better with the overall runup data, than the results from GOES. For Moín, Westfalia, Bananito, Puerto Vargas, and Puerto Viejo the three sources gave acceptable results. At Bananito, tsunami runup between 0.65 and $1.7 \mathrm{~m}$ was indicated in PW92 and all solutions resulted in values between that interval. The highest tsunami runup measured was of more
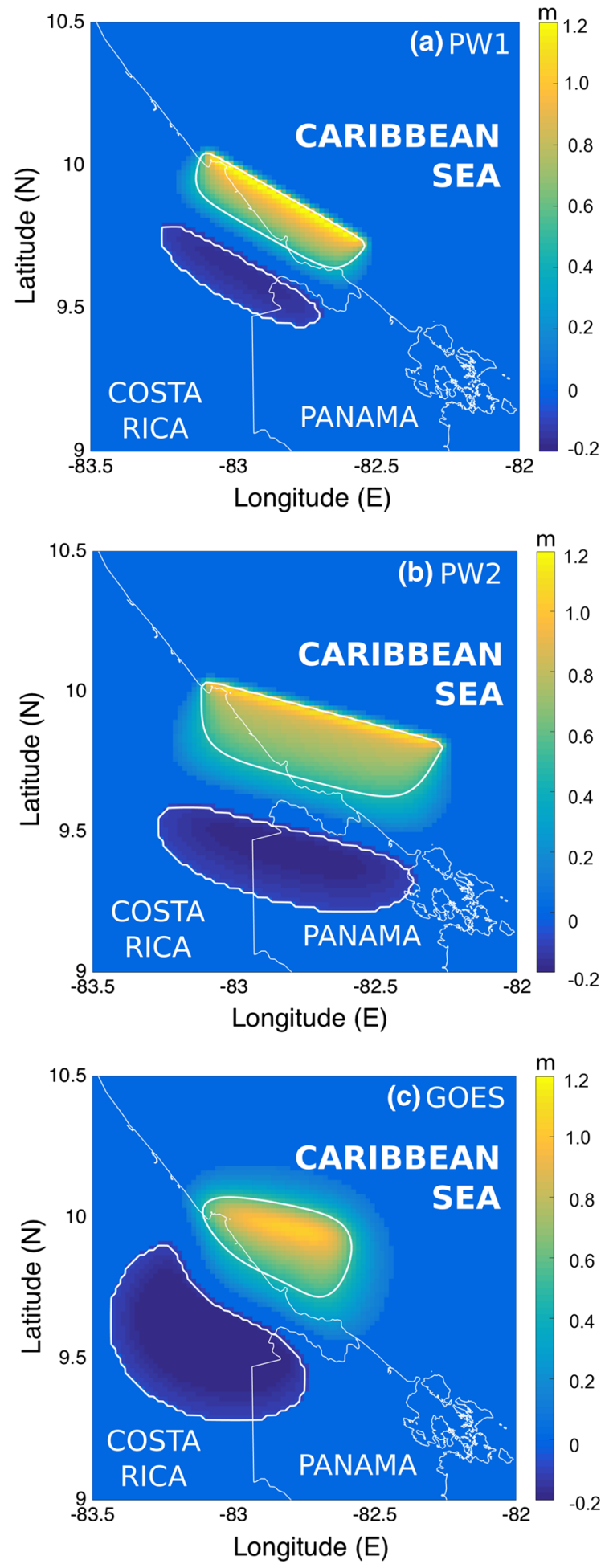

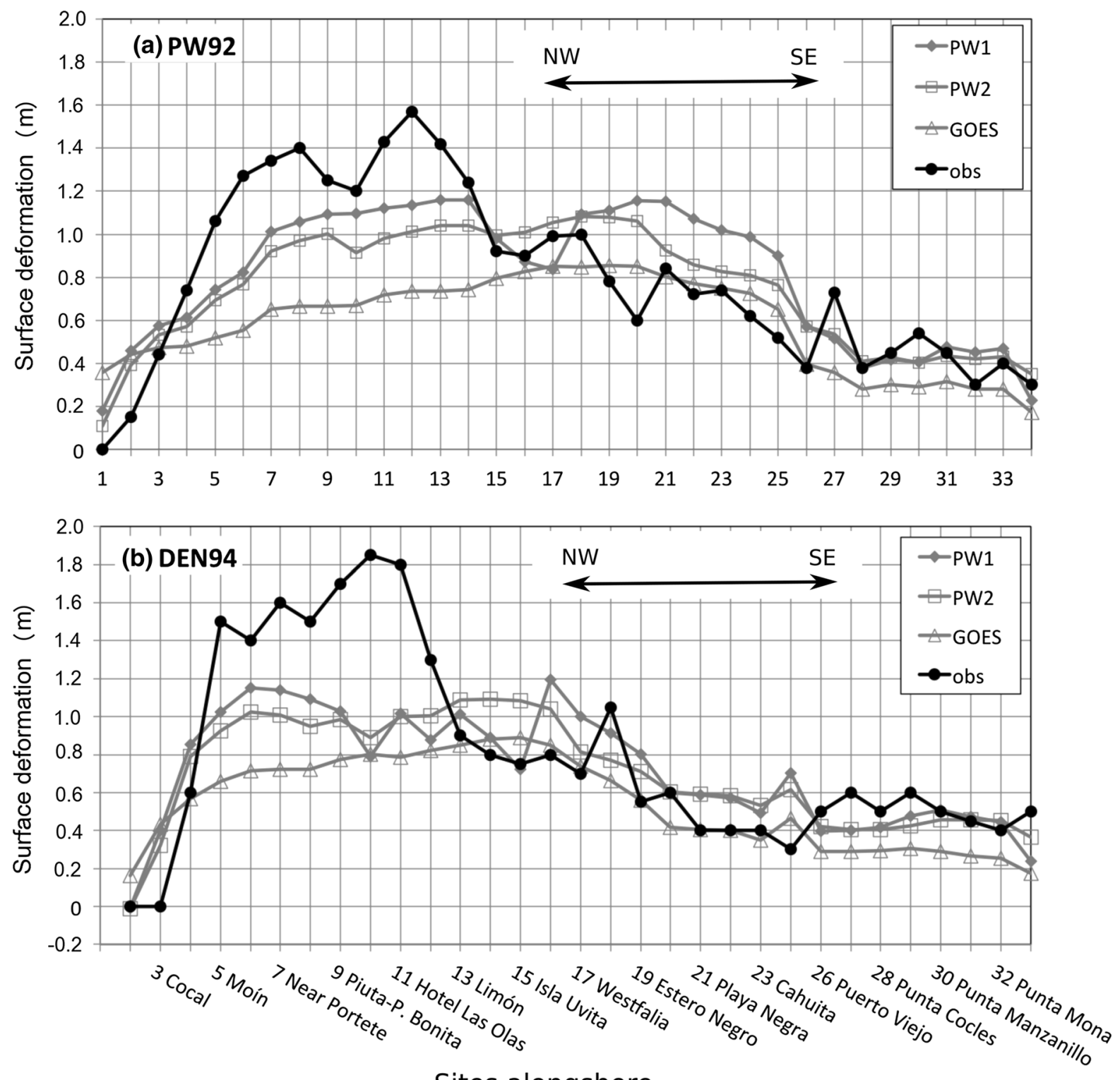

\section{Sites alongshore}

Figure 5

Comparison of coseismic uplift in meters measured by a PW92 and b DEN94 (black dots) with model results from PW1 (diamonds), PW2 (squares), and GOES (triangles). Location of data points in Fig. 3

than $2 \mathrm{~m}$ and was located at Punta Uva, for which PW1 and PW2 had a good agreement, but GOES underestimated it by approximately $1 \mathrm{~m}$. For Manzanillo $\mathrm{W}$ and $\mathrm{E}$ and Gandoca, all four sources performed in a similar way, with maximum differences with the measured runup of less than $50 \mathrm{~cm}$.

Considering the entire central and south Caribbean coastal region along Costa Rica, the highest tsunami heights modeled for the four solutions were located west from Cahuita point (Fig. 7). Maximum modeled tsunami heights were around $2.5 \mathrm{~m}$. Both solutions from PW92 resulted in tsunami heights over $1 \mathrm{~m}$ at Manzanillo (Fig. 6a and b), agreeing with reports of 1991 tsunami.

Maximum tsunami heights at Limón-Moín promontory were estimated to be less than $1.5 \mathrm{~m}$, without flooding, for PW1, PW2, and GOES solutions (Fig. 8b). No tsunami runup was reported here 
Table 3

Normalized root-mean-square deviation (NRMSD) for each solution related to each dataset

\begin{tabular}{llll}
\hline Data/solution & PW1 (\%) & PW2 (\%) & GOES (\%) \\
\hline PW92 & 32.30 & 32.45 & 48.54 \\
DEN94 & 44.56 & 45.31 & 57.71 \\
\hline
\end{tabular}

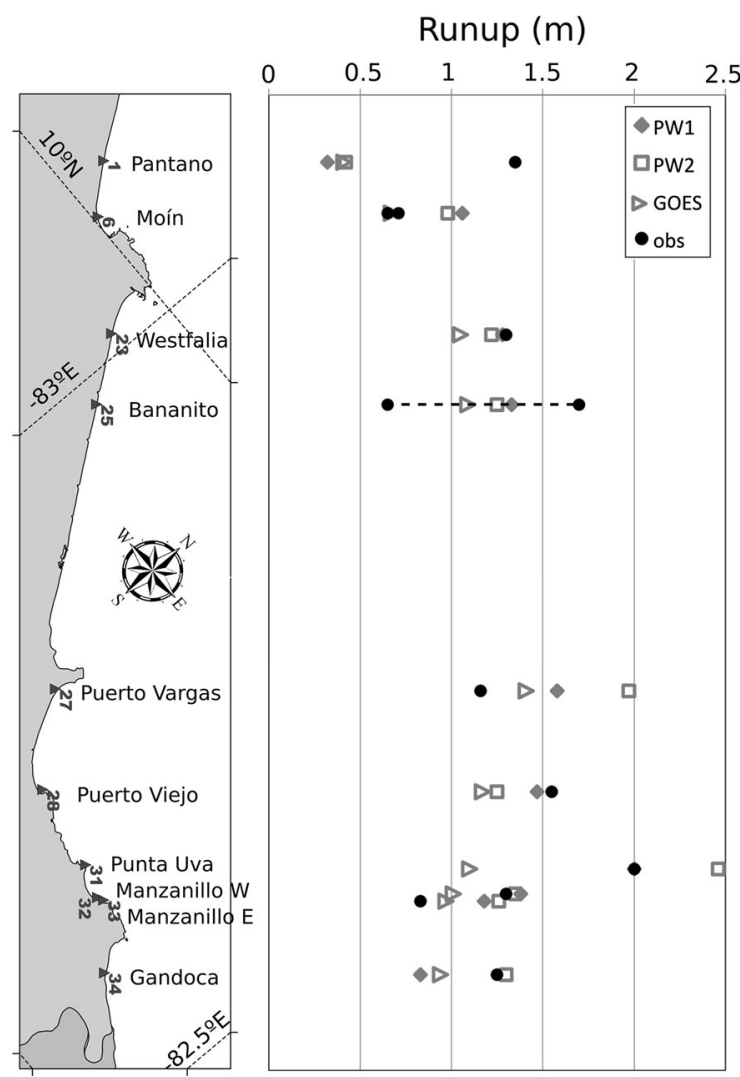

Figure 6

Comparison of runup in meters measured by PW92 (black dots) with model results from PW1 (diamonds), PW2 (squares), and GOES (triangles). Site numbers and names correspond with Plafker and Ward (1992) survey. For sites \#6 Moín and \#25 Bananito, the runup was given as a range of values, which is indicated with a dashed line

for 1991 event, very likely because the strong coastal uplift experienced at this promontory diminished the tsunami heights there.

\subsection{Hypothetical Worst Credible Seismic Source Offshore Limón (Mw 7.9)}

The hypothetical earthquake rupturing along the shallow part of the thrust fault led to almost $3 \mathrm{~m}$ of
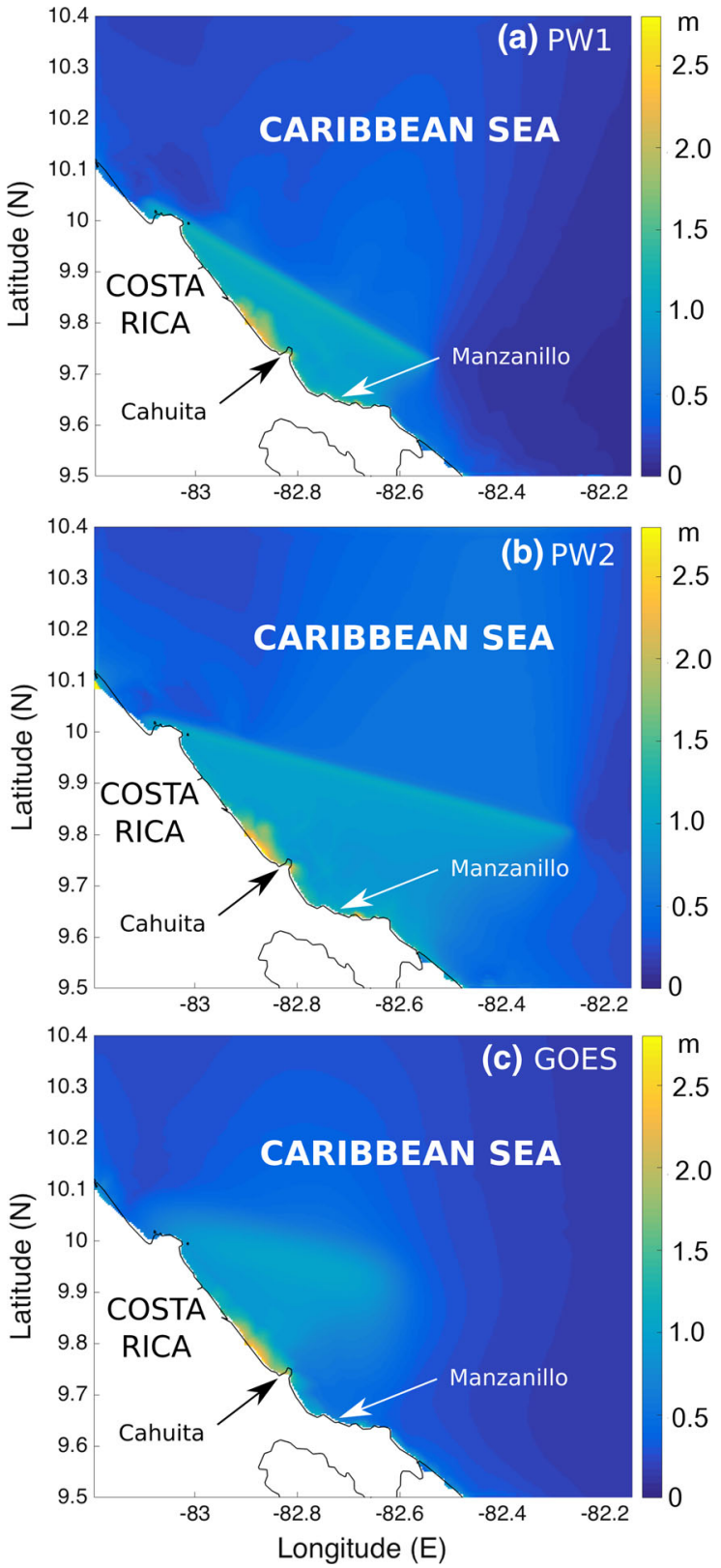

Figure 7

Maximum tsunami heights in meters modeled for the central and south Caribbean coast of Costa Rica using the source solutions from a PW1, b PW2, and c GOES

surface deformation (Fig. 9) triggering more than $5 \mathrm{~m}$ maximum tsunami heights (Fig. 11). The highest waves would be expected along south Costa Rica and the Panamá border. Particularly, this hypothetic event has a large mean slip occurring in shallower regions that the 1991 event. Larger subsidence could occur 

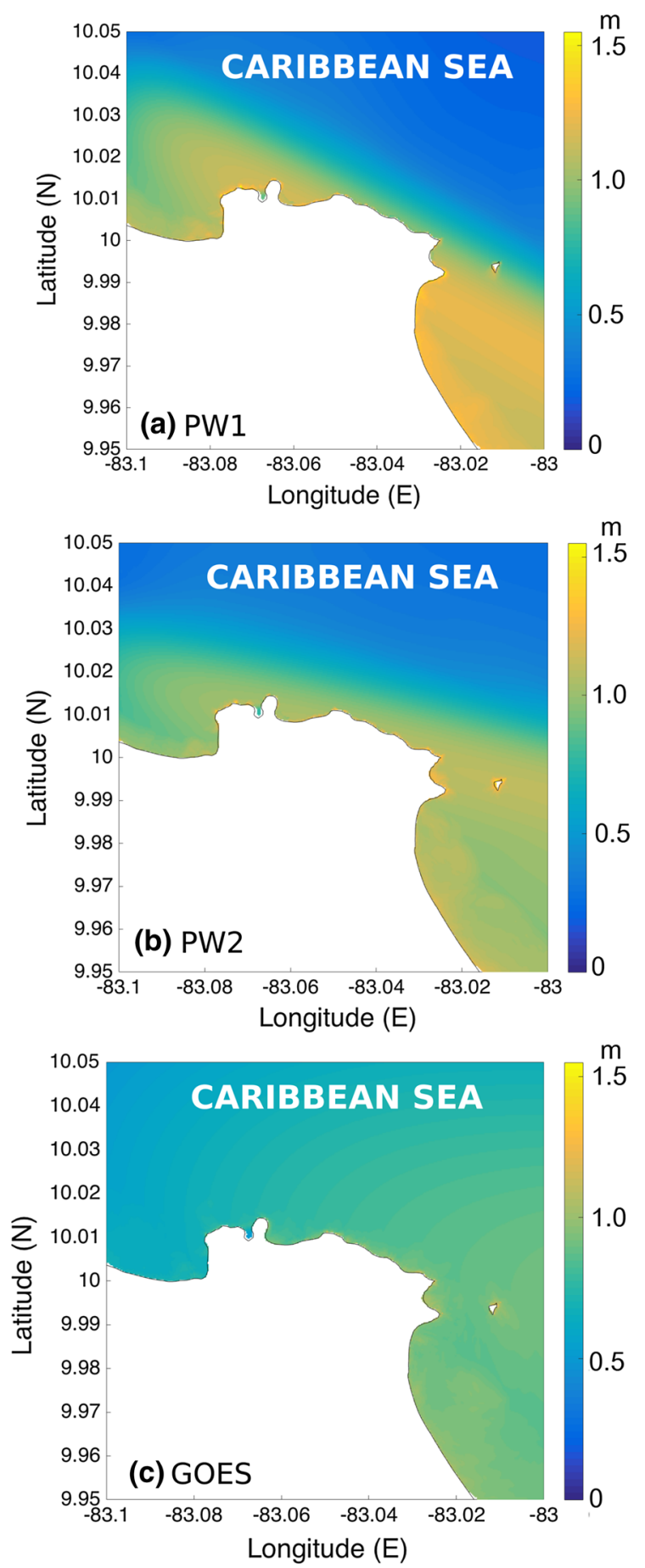

Figure 8

Maximum tsunami heights in meters modeled for Limón using the source solutions from a PW1, b PW2, and c GOES

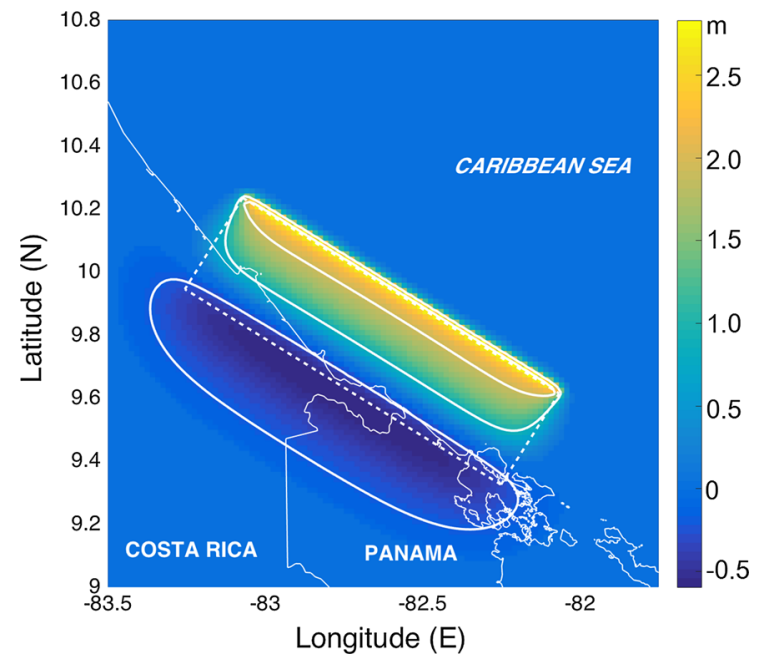

Figure 9

Coseismic deformation in meters obtained for the worst credible scenario Mw 7.9 offshore Limón. The thick dashed lines show the surface projection of the fault plane. The color scale is in meters and the contour lines correspond to coseismic deformation of -0.1 , 0.4 , and $0.8 \mathrm{~m}$, respectively.

offshore and near the shoreline, which would result in larger tsunami heights than 1991 tsunami greatly affecting Costa Rica and Panamá. Also, modeling results showed energy focusing to Nicaragua and San Andres Island (Colombian territory offshore Nicaragua) (Fig. 10). In Costa Rica the tsunami very likely would also have considerable effects in Limón city and Moín, where the main port is located (Fig. 11b).

\section{Discussion}

Limón-Moín promontory experienced the largest uplift associated to 1991 event, as measured between points 6 and 21 of PW92 data and between points 4 (Near Moín) and 16 (Muelle Alemán) of DEN94 data. Plafker and Ward (1992) and Denyer et al. (1994) suggest that this promontory is uplifting about $3 \mathrm{~mm} /$ year, and the region might experience similar earthquakes in moderate recurrence periods (200-1000 years). The uplift has been recorded in reef platforms along Limón-Moín promontory as well as Cahuita and Puerto Viejo. 


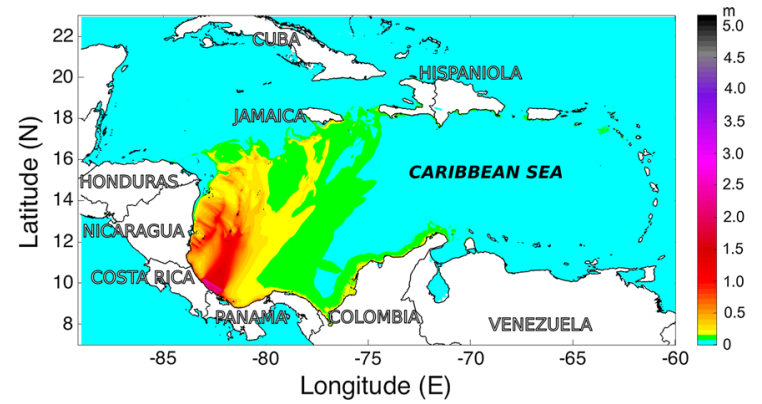

Figure 10

Maximum tsunami heights in meters for the worst credible scenario Mw 7.9 for the whole Caribbean region

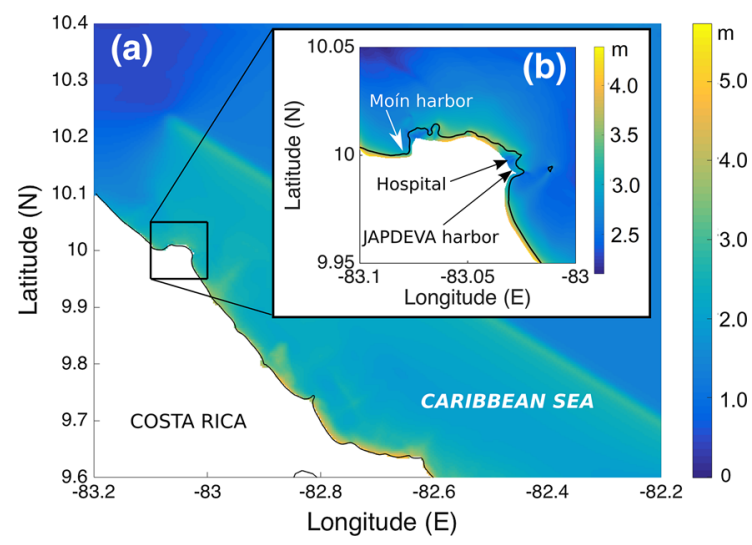

Figure 11

Maximum tsunami heights in meters for the worst credible scenario Mw 7.9 for Costa Rica. The thick black line in (a) shows the extent of (b)

In general, all solutions agreed better with the coseismic uplift measured at the southern part of the study region and underestimated it at the northern part, where Limón-Moín promontory is located. Plafker and Ward (1992) conclude that the fault geometry is more complex than a uniform slip, planar, rectangular dislocation approach used by them. Goes et al. (1993) indicates that body waves suggest a non-uniform slip with concentrated slip near Limón to explain the maximum coseismic uplift measured there. Also Denyer et al. (1994) postulate that secondary fault structures might be associated with the main rupture plane, due to the size of the rupture area, the complexity of the main event, and the amount of aftershocks. However, the limited understanding of the fault geometry and asperities in this region hampers an adequate modeling of the rupture (Goes et al. 1993).
Measurement of tsunami runup is more complicated than coseismic uplift, due to poor preservation of watermarks and limited reliability of eyewitnesses. In some sites the runup values of the 1991 tsunami are given as a lower limit of the possible inundation height. The modeling of the three solutions agreed well in general, with the exception of Pantano (Nueve Millas) and Puerto Vargas. PW1 and PW2 solutions adjusted better to the data than GOES solution at Westfalia, Puerto Viejo, Punta Uva, West Manzanillo, and Gandoca; but GOES solution adjusted better to runup data at Moín and East Manzanillo. Modeled tsunami heights were moderate around Limón-Moín promontory because this region experienced the highest coseismic uplift. No inundation was reported there very likely due to its abrupt coastal morphology as well as the uplift.

Tsunami inundation modeling depends largely on a good definition of the source, and a proper detailed bathymetric dataset. Tidal gauge records of a tsunami can be employed to constraint the seismic source when available. However, for this tsunami there were only three tidal gauge records in the far field, hindering the possibility of a tsunami inversion. Tsunami modeling results obtained here were not compared with those records due to poor preservation of the originals. The image files of those marigrams lack of axis scale and the image quality is not the best.

There are no reports of damages caused by the 1991 tsunami possibly because the coastal uplift and coral barrier served as protection or also because they were undermined due to earthquake damages. The earthquake caused great damage as consequence of the wide extent of liquefaction (Denyer et al. 1994). Despite most of southern Limón and Panamá border coastal areas being almost deserted in 1991, the touristic activity has grown considerably in the south Caribbean coast since then. There are many small hotels along the coast concentrated at Cahuita, Puerto Viejo, Cocles, and Manzanillo with increasing local population almost all year round. This is critical if we consider that numerical models based on scenarios PW1 and PW2 resulted on tsunami heights of over $2 \mathrm{~m}$ at the mentioned places. Moreover, our hypothetical scenario shows that tsunami heights up to $6 \mathrm{~m}$ could affect critical facilities and coastal towns. 
The building regulations have been strengthened since the 1991 earthquake in that region of Costa Rica (CFIA 2003) and it is expected that a similar earthquake would not produce such damages nowadays. Nonetheless, key actions such as evacuation plans have not been developed to increase tsunami preparedness. The region along the coast consists on a narrow planar extension followed by small mountains. Even when the slope might be suitable for evacuation, the main road runs alongshore and there are only few pathways as well as rough gravel secondary roads running uphill (Fig. 3). The slopes are covered with dense rainforest, and the infrastructure in the area consists mostly of wooden buildings with up to two stories, which hinder cross-country and vertical evacuation.

Finally, evacuation plans and multi-hazard mapping are still lacking in this area, which is also exposed to strong erosion caused by wind waves. Particularly, during storm surges the sea has inundated some parts of the main road and some houses in this region (e.g., January 2015), showing the vulnerability of possible evacuation routes for both tsunami and storm events. Evacuation maps should be done based on high-resolution grids $\sim 10 \mathrm{~m}$, but unfortunately bathymetry datasets with such resolution are not yet available for this area. However, the resolution of the bathymetric datasets employed in this study might be enough for preliminary tsunami evacuation maps.

\section{Conclusions}

Three seismic solutions of 1991 Limón earthquake were employed as initial conditions for the modeling of tsunami propagation and runup. The coseismic deformation modeled after PW1 solution agreed better with the measured coseismic deformation and runup than the results from PW2 and GOES solutions. All three seismic solutions underestimated the coseismic uplift at Limón-Moín promontory, very likely due to heterogeneities in the fault not accounted here. Considering the limited knowledge of the seismic source and the coarse resolution of the bathymetry employed, PW1, PW2, and GOES solutions had a reasonable agreement with coseismic uplift data, particularly south of Limón-Moín promontory. Those three solutions had also a good agreement with runup data; their maximum runup was $2.46 \mathrm{~m}$ at Punta Uva, where was measured as the maximum runup for Costa Rica of at least $2 \mathrm{~m}$.

The tsunami caused by the 1991 earthquake was not negligible, and a similar event might have larger impact nowadays considering the increase on touristic visitation and coastal development. Not to mention the possible consequences of the larger event simulated here as a worst-case scenario with magnitude $\mathrm{Mw}$ 7.9, which could generate maximum runup values of over $5 \mathrm{~m}$. The south Caribbean coast could be considered even more vulnerable to tsunamis due to the fishing villages close to the seaside and the typical architecture with prevailing small hotels and wooden houses up to two floors, one main road running alongshore and scarce uphill roads through dense vegetation, all of which delay people evacuation.

Due to its vulnerability and the tsunami threat exposed in this work, the development of tsunami evacuation maps and plans is recommended for the Caribbean coast of Costa Rica. However, finer and updated bathymetry and more complex source models are required to perform more accurate tsunami modeling, considering the significant coseismic deformation caused by the 1991 earthquake and the lack of bathymetry data afterwards.

\section{REFERENCES}

Adamek, S., Frohlich, C., \& Pennington, W. D. (1988). Seismicity of the Caribbean-Nazca Boundary: Constraints on microplate tectonics of the Panamá region. Journal of Geophysical Research: Solid Earth, 93(B3), 2053-2075. doi:10.1029/ JB093iB03p02053.

Benito, M. B., Lindholm, C., Camacho, E., Climent, A., Marroquín, G., Molina, E., et al. (2012). A new evaluation of seismic hazard for the Central America Region. Bulletin of the Seismological Society of America, 102(2), 504-523. doi:10.1785/0120110015.

Blaser, L., Kruger, F., Ohrnberger, M., \& Scherbaum, F. (2010). Scaling relations of earthquake source parameter estimates with special focus on subduction environment. Bulletin of the Seismological Society of America, 100(6), 2914-2926. doi:10.1785/ 0120100111.

Borrero, J. C., Kalligeris, N., Lynett, P. J., Fritz, H. M., Newman, A. V., \& Convers, J. A. (2014). Observations and modelling of the August 27, 2012 earthquake and tsunami affecting El 
Salvador and Nicaragua. Pure and Applied Geophysics, 171(12), 3421-3435. doi:10.1007/s00024-014-0782-2.

Boschini, I., \& Montero, W. (1994). Sismicidad histórica e instrumental del Caribe de Costa Rica. Revista Geológica de América Central, Vol. Esp. Terremoto de Limón, pp.65-71.

Camacho, E. (1994). El tsunami del 22 de abril de 1991 en Bocas del Toro, Panamá. Revista Geológica de América Central, Vol. Esp. Terremoto de Limón, pp. 61-64.

Camacho, E., Hutton, W., \& Pacheco, J. F. (2010). A new look at evidence for a Wadati-Benioff zone and active convergence at the North Panamá deformed belt. Bulletin of the Seismological Society of America, 100(1), 343-348. doi:10.1785/ 0120090204.

Camacho, E., \& Víquez, V. (1993). Historical seismicity of the North Panamá deformed belt. Revista Geológica de América Central, 15, 49-64.

CFIA. (2003). Código Sísmico de Costa Rica (3rd ed.). Cartago: Editorial Tecnológica de Costa Rica.

Denyer, P., Arias, O., \& Personius, S. (1994). Efecto tectónico del terremoto de Limón. Revista Geológica de América Central, Vol. Esp. Terremoto de Limón, pp. 39-52.

Fernández, M. (2013). Seismotectonic and the hipothetical strikeslip tectonic boundary of Central Costa Rica. In D'Amico S (ed.) Earthquake research and analysis-New advances in seismology. doi: 10.5772/54989. http://www.intechopen.com/books/earth quake-research-and-analysis-new-advances-in-seismology/seismo tectonic-and-the-hipothetical-strike-slip-tectonic-boundary-of-cen tral-costa-rica.

Fernández-Arce, M., Molina, E., \& Havskov, J. (2000). Tsunamis and tsunami hazards in Central America. Natural Hazards, 22, 91-116.

Fritz, H. M., Hillaire, J. V., Molière, E., Wei, Y., \& Mohammed, F. (2013). Twin tsunamis triggered by the 12 January 2010 Haiti Earthquake. Pure and Applied Geophysics, 170(9-10), 1463-1474. doi:10.1007/s00024-012-0479-3.

Geist, E. L., \& Parsons, T. (2006). Probabilistic analysis of tsunami hazards. Natural Hazards, 37(3), 277-314. doi:10.1007/s11069005-4646-z.

Goes, S. D. B., Velasco, A., Schwartz, S., \& Lay, T. (1993). The April 22, 1991, Valle de la Estrella, Costa Rica $(\mathrm{Mw}=7.7)$ earthquake and its tectonic implications: A broadband seismic study. Journal of Geophysical Research, 98(B5), 8127-8142.

Harbitz, C. B., Glimsdal, S., Bazin, S., Zamora, N., Løvholt, F., Bungum, H., et al. (2012). Tsunami hazard in the Caribbean: Regional exposure derived from credible worst case scenarios. Continental Shelf Research, 38, 1-23. doi:10.1016/j.csr.2012.02. 006.

Hayes, G. P., McNamara, D. E., Seidman, L., \& Roger, J. (2013). Quantifying potential earthquake and tsunami hazard in the Lesser Antilles subduction zone of the Caribbean region. Geophysical Journal International, 196(1), 510-521. doi:10.1093/ gji/ggt385.

IOC/UNESCO (2014) User's guide for the pacific tsunami warning center enhanced products for the Pacific Tsunami warning system. IOC Technical Series 108.

IOC/UNESCO (2015) Exercise caribe wave/LANTEX 15 A Caribbean and Northwestern Atlantic tsunami warning exercise. IOC Technical Series 112.

Lander, J. F., Whiteside, L. S., \& Lockridge, P. A. (2002). A brief history of tsunamis in the Caribbean Sea. Science of Tsunami Hazards, 20(1), 57-94.
López, A. M., Chacón-Barrantes, S., Sánchez, R., \& Luque, N. (2016). Modeling the CaribeWave2015 tsunami exercise scenario: An initiative of a Caribbean-based collaborative modeling group. In IASPEI II regional assembly Latin American and Caribbean seismologic commision (LACSC). San José, Costa Rica, TU_P018.

López, A. M., Chacón-Barrantes, S., Zamora, N., Audemard, F. A., Dondin, F., Clouard, V., Løvholt, F., Harbitz, C., Vanacore, E. A., \& Huérfano, V. (2015). Tsunamis from tectonic Sources along Caribbean plate boundaries. In AGU fall meeting abstracts. San Francisco, T11E-2942.

Løvholt, F., Glimsdal, S., Harbitz, C. B., Zamora, N., Nadim, F., Peduzzi, P., et al. (2012). Tsunami hazard and exposure on the global scale. Earth-Science Reviews, 110, 58-73. doi:10.1016/j. earscirev.2011.10.002.

Lundgren, P., Protti, M., Donnellan, A., Heflin, M., Hernández, E., \& Jefferson, D. (1999). Seismic cycle and plate margin deformation in Costa Rica: GPS observations from 1994 to 1997. Journal of Geophysical Research, 104, 28915-28926.

Lundgren, P., Wolf, S. K., Protti, M., \& Hurst, K. J. (1993). GPS measurements of crustal deformation associated with the 22 April 1991, Valle de la Estrella, Costa Rica earthquake. Geophysical Research Letters, 20(5), 407-410.

Mercado, A., \& McCann, W. (1998). Numerical simulation of the 1918 Puerto Rico tsunami. Natural Hazards, pp. 1-20. http:// link.springer.com/article/10.1023/A:1008091910209.

Montero, C., Segura, J., Malavassi, E., Güendel, F., González, V., Fernández, E., de Obaldía, F., Rojas, D., Rodríguez, H., Mata, A., Van Der Laat, R., Barboza, V., Barrantes, O., Marino, T., \& McNally, K. (1991). Informe Preliminar Terremoto 22 de abril 1991, Ms 7.4 Valle de la Estrella, Limón, Costa Rica, OVSICORI-UNA.

NGDC/WDS. (2015). National geophysical data center, world data service. Global Historical Tsunami Database. National Geophysical Data Center, NOAA. http://www.ngdc.noaa.gov/hazard/ tsu_db.shtml. Accessed Aug. 2016.

Nishenko, S. P., Camacho, E., Astorga, A., Morales, L. D., \& Preuss, J. (1995). The 1991 Limón, Costa Rica Tsunami. Natural Hazards, submitted.

Okada, Y. (1985). Surface deformation due to shear and tensile faults in a half-space. Bulletin of Seismological Society of America, 75(4), 1135-1154.

Pacheco, J. F., \& Sykes, L. R. (1992). Seismic moment catalog of large shallow earthquakes, 1900 to 1989. Bulletin of the Seismological Society of America, 82(3), 1306-1349.

Parsons, T., \& Geist, E. L. (2008). Tsunami probability in the Caribbean Region. Pure and Applied Geophysics, 165(11-12), 2089-2116. doi:10.1007/s00024-008-0416-7.

Pennington, W. (1981). Subduction of the Eastern Panamá Basin and seismotectonics of northwestern South America. Journal of Geophysical Research, 86, 10753-10770.

Plafker, G., \& Ward, S. N. (1992). Backarc thrust faulting and tectonic uplift along the Caribbean Sea coast during the April 22, 1991 Costa Rica earthquake. Tectonics, 11(4), 709-718.

Protti, M., \& Schwartz, S. Y. (1994). Mechanics of back arc deformation in Costa Rica: Evidence from an aftershock study of the April 22, 1991, Valle de la Estrella, Costa Rica, earthquake $(\mathrm{Mw}=7.7)$. Tectonics, 13(5), 1093-1107.

Roger, J., Dudon, B., \& Zahibo, N. (2013). Tsunami hazard assessment of Guadeloupe Island (F.W.I.) related to a megathrust rupture on the Lesser Antilles subduction interface. Natural 
Hazards and Earth System Science, 13(5), 1169-1183. doi:10. 5194/nhess-13-1169-2013.

Satake, K. (1994). Mechanism of the 1992 Nicaragua tsunami earthquake. Geophysical Research Letters, 21(23), 2519-2522. doi:10.1029/94GL02338.

Schwartz, S. Y. (1995). Source parameters of aftershocks of the 1991 Costa Rica and 1992 Cape Mendocino, California, Earthquakes from inversion of local amplitude ratios and broadband waveforms. Bulletin of the Seismological Society of America, 85(6), 1560-1575.

Silver, E. A., Galewsky, J., \& McIntosh, K. D. (1995). Variation in structure, style, and driving mechanism of adjoining segments of the North Panamá deformed belt. Geological Society of America Special Papers, 295, 225-234.

Silver, E. A., Reed, D. L., Tagudin, J. E., \& Heil, D. J. (1990). Implications of the North and South Panamá Thrust Belts for the origin of the Panamá Orocline. Tectonics, 9(2), 261-281.
Suárez, G., Pardo, M., Domínguez, J., Ponce, L., Montero, W., Boschini, I., et al. (1995). The Limón, Costa Rica earthquake of April 22, 1991: Back arc thrusting and collisional tectonics in a subduction environment. Tectonics, 14(2), 518-530.

Trenkamp, R., Kellogg, J. N., Freymueller, J. T., \& Mora, H. P. (2002). Wide plate margin deformation, southern Central America and northwestern South America, CASA GPS observations. Journal of South American Earth Sciences, 15(2), 157-171. doi:10.1016/S0895-9811(02)00018-4.

Yamazaki, Y., Cheung, K. F., \& Kowalik, Z. (2010). Depth-integrated, non-hydrostatic model with grid nesting for tsunami generation, propagation, and run-up. International Journal for Numerical Methods in Fluids, 67, 2081-2107. doi:10.1002/fld. 2485.

Zahibo, N., Pelinovsky, E., Yalciner, A. C., Kurkin, A., Koselkov, A., \& Zaitsev, A. (2003). The 1867 virgin island tsunami. Natural Hazards and Earth System Sciences, 3, 367-376.

(Received September 21, 2016, accepted July 21, 2017) 